Retraction

\title{
Retracted: Genetic and Functional Profiling of Crohn's Disease: Autophagy Mechanism and Susceptibility to Infectious Diseases
}

\author{
BioMed Research International \\ Received 7 October 2013; Accepted 7 October 2013 \\ Copyright (C) 2013 BioMed Research International. This is an open access article distributed under the Creative Commons \\ Attribution License, which permits unrestricted use, distribution, and reproduction in any medium, provided the original work is \\ properly cited.
}

This article has been retracted as it is found to contain a substantial amount of material from published papers. The three most plagiarized papers are: (1) I. Sekirov, S. L. Russell, L. C. Antunes and B. B. Finlay, "Gut microbiota in health and disease," Physiological Reviews, vol. 90, no. 3, pp. 859-904, 2010. (2) V. M. Hubbard and K. Cadwell, "Viruses, autophagy genes, and Crohn's disease," Viruses, vol. 3, no. 7, pp. 1281-1311, 2011. (3) B. Khor, A. Gardet and R. J. Xavier, "Genetics and pathogenesis of inflammatory bowel disease," Nature, vol. 474, no. 7351, pp. 307-317, 2011 [1].

\section{References}

[1] A. Marcuzzi, A. M. Bianco, M. Girardelli et al., "Genetic and functional profiling of Crohn's disease: autophagy mechanism and susceptibility to infectious diseases," BioMed Research International, vol. 2013, Article ID 297501, 11 pages, 2013. 